\title{
PONDOK PESANTREN SEBAGAI WADAH MODERASI ISLAM DI ERA GENERASI MILENIAL
}

\author{
Neny Muthi'atul Awwaliyah \\ Mahasiswa Fakultas Ushuluddin dan Pemikiran Islam \\ Jurusan Aqidah dan Filsafat Islam \\ Konsentrasi Studi al-Qur'an dan Hadis UIN Sunan Kalijaga Yogyakarta \\ Email: nenyulthia@gmail.com
}

\begin{abstract}
From the pesantren's womb figures were born who helped declarator and motorized the progress of the nation. However, in the recent development of boarding schools such as losing direction and identity in navigating the era of modernization. There are several traditions in the pesantren that are missing, such as intensive recitation of the sorogan and bandongan systems, which are proven to have produced reliable pesantren alumni who in the past were important elements in the pesantren system and curriculum. It should, when there is an effort to revitalize and optimize some of the important elements in the pesantren, the contribution of pesantren to the Indonesian nation will not be questioned anymore. This study aims to track pesantren religious thoughts and movements in the era of globalization. As well as describing the Islamic spirit of the santri in the pesantren environment which continues to be sought as a fortress for Muslims, In line with the millennial era, the faces of Islamic boarding schools in Indonesia are no longer monopolized by traditional groups or radicals, but have been colored by new pesantren formed by other Islamic groups with different faces.
\end{abstract}

Keywords: Islamic Boarding School, Islamic Moderation, Contemporary Era.

\section{Abstrak}

Dari rahim pesantren lahir tokoh-tokoh yang turut menjadi deklarator dan motor kemajuan bangsa. Namun, dalam perkembangan mutakbirnya pesantren seperti kebilangan arah dan jati diri dalam mengarungi era modernisasi. Ada beberapa tradisi dalam pesantren yang bilang seperti pengajian intensif sistem sorogan dan bandongan adalah justru yang terbukti telab menelorkan alumnus pesantren yang handal yang pada zaman dahulu merupakan elemen penting dalam sistem dan kurikulum pesantren. Mestinya, ketika ada upaya revitalisasi dan optimalisasi beberapa elemen penting dalam pesantren tersebut, sumbangsih pesantren bagi bangsa Indonesia tidak akan dipertanyakan lagi. Kajian ini bertujuan untuk melacak pemikiran dan gerakan keagamaan pesantren di era globalisasi. Serta menggambarkan semangat Islam dari kalangan para santri di lingkungan pesantren yang terus diupayakan sebagai benteng pertahanan umat Islam, Sejalan dengan Era generasi millenial, wajah pesantren di Indonesia sudah tidak lagi dimonopoli oleh 
Neny Muthi'atul Awwaliyah

kelompok tradisional atau fundamental-radikal, melainkan sudah diwarnai oleh pesantrenpesantren baru yang dibentuk oleh kelompok. Islam lainnya dengan wajah yang berbeda pula.

Kata kunci: Pesantren, Moderasi Islam, Era kontemporer.

\section{A. Pendahuluan}

Pesantren di Indonesia selama ini dipandang terlalu menekankan aspekaspek tradisional dan konservatisme, yang mengesampingkan kemampuannya untuk mengembangkan diri dalam kehidupan modern. Penggolongan orang-orang yang hidup dalam dunia pesantren selalu digambarkan sebagai orang-orang Islam yang 'kolot'. Clifford Geertz ${ }^{1}$ berpendapat bahwa salah satu sifat kekolotan itu adalah adanya penerimaan mereka terhadap elemen-elemen sinkretis yang bertentangan dengan Islam itu sendiri. Namun demikian, ironisnya bahwa identifikasi tentang Islam yang dipandang kolot ini berbanding lurus dengan apa yang disimpulkan oleh Geertz tentang ciri-ciri 'abangan' yang merupakan campuran dari kehidupan keagamaan yang bersifat animistis, Hindu-Budhistis dan Islam. Sebaliknya, Alan Samson $^{2}$ yang menggambarkan wajah Islam 'kolot' di Indonesia, khususnya di Jawa sebelum kemerdekaan, adalah sebagai penganut suatu sistem keagamaan yang didasarkan pada campuran dari elemen-elemen animisme, Hindu-Budhisme dan juga Islam. Hal ini justru menunjukkan kesimpangsiuran antara pendapat Geertz dan Samson mengenai sifat-sifat 'Islam abangan' dan 'Islam kolot'.

Dalam tulisan lain, Geertz ${ }^{3}$ membandingkan bagaimana Islam berkembang di Indonesia (Jawa) dan di Timur Tengah (Maroko) dengan mengatakan bahwa Islam yang masuk ke Indonesia secara sistematis baru terjadi pada abad ke-14, yaitu bertepatan dengan suatu kebudayaan besar yang telah menciptakan suatu sistem politik, nilai-nilai estetika, dan juga kehidupan sosial keagamaan yang maju. Faktanya, kehidupan sosial yang dikembangkan oleh Kerajaan Hindu-Budha di Jawa telah mampu menanamkan akar yang sangat kuat dalam kehidupan masyarakat Indonesia. Bahkan, menurut Geertz, jika dibandingkan dengan kehidupan Islam itu sendiri yang

1 Geertz, C, Religious Belief and Economic Behavior in a Central Javanese Town: Some Preliminary Considerations, dalam Economic Developement and Cultural Change, Vol. IV, No. 2, Januari. (The Free Press of Glencoe: 1956), hlm.7.

2 Samson Alan, Islam in Indonesia Politics, dalam Asian Survey, No. 8 Desember. 1968, hlm. 23

3 Geertz, C. Islam Observed, (New Haven London: Yale University Press, 1968), hlm. 38. 
berlangsung di India, Islam di Indonesia sangat lemah dan tidak mengakar dikarenakan bersifat sementara, sinkretis, dan berwajah majemuk ${ }^{4}$.

Meski demikian, pandangan Geertz $\left(1968^{5}\right)$ di atas hanya membahas Islam yang fokus di Jawa untuk digeneralisir sebagai Islam di Indonesia, dan hanya terbatas di kraton-kraton yang pada masa kolonial Belanda terlepas sama sekali dari sumbernya tanpa memiliki lembaga-lembaga pendidikan yang oleh Geertz sendiri diakui sebagai syarat bagi pengembangan Islam di Indonesia. Dalam tulisannya yang kedua ini Islam Observed, pada $1968^{6}$, Geertz justru tidak banyak menyebut bahkan menjelaskan secara lebih mendalam tentang 'Islam santri' dalam lingkungan pesantren, sebagaimana ia singgung dalam tulisan-tulisan sebelumnya The Javanese Family, pada $1960^{7}$; dan Modernization in a Moslem Society: The Indonesian Case, pada $1963 .^{8}$

Untuk memahami kondisi di lingkungan pesantren dan juga dalam kehidupan sosial kemasyarakatan, maka perlu terlebih dahulu diuraikan di sini secara singkat mengenai berbagai kondisi sosial, budaya, politik dan ekonomi dari lembaga-lembaga pengajian dan juga pesantren pada periode sebelumnya di masa lalu yang memiliki korelasi dengan berbagai kondisi yang berlangsung saat ini. Adapun kondisi yang dimaksud adalah yang berlangsung sejak Islam pertama kali masuk ke Jawa, yaitu pada abad ke-13. Hal ini dipandang perlu dikarenakan kategorisasi atau pengelompokan yang terjadi sampai saat ini antara Islam tradisional dan Islam modern, dan dalam batas-batas tertentu, dikarenakan adanya konflik antara ajaran Islam (yang dibawa oleh para pedagang dan pendakwah dari Timur Tengah) dengan ajaran Kristen (yang dibawa oleh para pedagang dan misionaris dari Belanda). Kondisi ini terus berlangsung pada periode Indonesia modern sekarang ini, yang

${ }^{4}$ Geerz C, The Religion of Java, (The Free Press of Glencoe, 1960), hlm. 97.

5 Geertz C, Islam Observed. (New Haven London: Yale University Press, 1968) hlm. 19.

${ }^{6}$ Geertz. C, Islam Observed..., hlm 23.

7 Geertz C, The Javanese Family. (The Free Press of Glencoe: 1960), hlm. 38.

${ }^{8}$ Geertz C, Modernization in a Moslem Society: The Indonesian Case, QUEST, Vol. 39, (Bombay: 1963), hlm. 29. 
Neny Muthi'atul Awwaliyah

justru sebagian disebabkan oleh adanya pola (pattern) dalam ajaran Islam itu sendiri yang dianut oleh mayoritas masyarakat Indonesia. ${ }^{9}$

Pasca terjadinya peledakan bom di W'TC dan menara pentagon di Amerika Serikat, isu seputar radikalisme dan terorisme kembali menghiasi pemberitaan dan beberapa media, baik cetak maupun elektronik. Setelah peristiwa itu, terjadi pengeboman Hotel JW. Marriot, pengeboman di Jl. Legian Bali dan peristiwa lain yang dilakukan oleh sekelompok tertentu dengan mengusung simbolsimbol agama. Kelompok radikal ini semakin merajalela dalam melakukan aktifitas gerakannya, dengan meruntuhkan nilai-nilai kemanusiaan atas nama agama. Sayangnya, perilaku kekerasan atas nama agama ini secara simplistik dikaitkan dengan kelompok agama tertentu dan institusi pendidikan tertentu, salah satunya adalah pesantren.

\section{B. Pesantren}

Kata pesantren berasal dari kata santri yang diberi awalan 'pe' dan akhiran 'an' yang dikarenakan pengucapan kata itu kemudian berubah menjadi terbaca 'en' (pesantren), yaitu sebutan untuk bangunan fisik atau asrama di mana para santri bertempat. Pesantren, kerap diartikan sebagai asrama tempat santri atau tempat murid murid belajar mengaji dan sebagainya. ${ }^{10}$ Dalam komunitas pesantren ada santri, ada kiai, ada tradisi pengajian serta tradisi lainnya, ada pula bangunan yang dijadikan para santri untuk melaksanakan semua kegiatan selama 24 jam. Saat tidur pun para santri menghabiskan waktunya di asrama pesantren. Tempat itu dalam bahasa Jawa dikatakan pondok atau pemondokan. Adapun kata santri sendiri berasal dari kata cantrik, yang berarti murid dari seorang resi yang juga biasanya menetap dalam satu tempat yang dinamakan dengan padepokan. Pesantren mempunyai persamaan dengan padepokan dalam beberapa hal, yakni adanya murid (cantrik dan santri), adanya guru (kiai dan resi), adanya bangunan (pesantren dan padepokan), dan terakhir adanya kegiatan belajar mengajar. ${ }^{11}$

\footnotetext{
${ }_{9}^{9}$ Dhofier, Z. Tradisi Pesantren: Studi tentang Pandangan Hidup Kiyai, (Jakarta: LP3ES, 1982), hlm. 87-88.

${ }^{10}$ Kamus Besar Bahasa Indonesia, 2005 hlm. 866

11 . Anwar, Ali. PembaruanPendidikan Pesantren Lirboyo Kediri, (Yogyakarta: Pustaka Belajar, 2011), hlm. 52.
} 
Meski bisa dikatakan pesantren ada unsur keidentikan dengan padepokan, tetapi tidak lantas benar kalau dikatakan pesantren adalah hasil adopsi dari padepokan. Sistem dan metodologi pembelajaran dalam pesantren lebih banyak kemiripan corak dengan 'Asshabu Shuffah' di Madinah. Kalau diumpamakan hadis, justru terhadap golongan inilah pesantren bersanad. Selain identik, kalau mau mengurutkan sejarah pesantren, maka akan ditemukan adanya persambungan sanad antara pesantren dengan Asshab al-Suffah. Golongan yang masyhur dengan nama asshab al-suffah itu adalah sekelompok sahabat Nabi yang tidak punya tempat tinggal dan menggunakan serambi masjid sebagai tempat tinggalnya. Abu Hurairah adalah maskot kelompok ashab al-suffah dan paling banyak meriwayatkan hadis Nabi. Mereka menyandarkan hidup dari pemberian sahabat dan Nabi sendiri. Sekumpulan sahabat pecinta ilmu itu menghabiskan waktu dengan mengikuti setiap gerak-gerik Nabi, baik dari sikap maupun perkataan (Qawlan wa FiLan). Dari kalangan mereka, kerap muncul para sahabat yang menjadi sumber rujukan dalam hadis Nabi. ${ }^{12}$

Pondok pesantren muncul pertama kali di Indonesia pada abad ke-16 M, yakni terdapat di Ampel Denta dalam asuhan Sunan Ampel. Pada waktu itu, beliau mengkader santri-santrinya untuk menyebarkan ajaran Islam ke seluruh pelosok tanah air, bahkan ada yang ditugaskan hingga ke negara-negara tetangga. Dari muridmurid Sunan Ampel inilah, kemudian menjamur pesantren-pesantren di seluruh penjuru tanah air. Puncaknya adalah pada awal pertengahan abad ke-19 serta awal abad ke-20, yaitu pada masa Syekh Kholil Bangkalan. Dari tangan dingin beliaulah muncul kiai-kiai besar Nusantara yang kemudian dapat menetaskan kiai-kiai besar lainnya. Puncaknya, pada waktu itu hampir di setiap kota kecamatan hingga di setiap desa berdiri satu pesantren atau bahkan lebih. Dalam perjalanannya, muncul pengklasifikasian pesantren di Indonesia berdasarkan sistem atau jenis lembaga pendidikan yang diadakannya. ${ }^{13}$

12 Sutrisno, Budiono Hadi, Sejarah Walisongo Misi Pengislaman di Tanah Jawa, Yogyakarta: GRAHA Pustaka, 2009), hlm. 37.

${ }^{13}$ Sutrisno, Budiono Hadi, Sejarah Walisongo Misi Pengislaman di Tanah Jawa ..., 2009, hlm. 16. 
Neny Muthi'atul Awwaliyah

\section{Pesantren Modern}

Menurut Barnawi, pesantren modern telah mengalami transformasi yang sangat signifikan. Pesantren ini telah dikelola dengan manajemen dan administrasi yang sangat rapi dan sistem pengajarannya dilaksanakan dengan porsi yang sama antara pendidikan agama dan pendidikan umum, dan penguasaan bahasa Inggris dan bahasa Arab. Sejak pertengahan tahun 1970-an pesantren telah berkembang dan memiliki pendidikan formal yang merupakan bagian dari pesantren tersebut mulai pendidikan dasar, pendidikan menengah bahkan sampai pendidikan tinggi, dan pesantren telah menerapkan prinsip-prinsip manajemen. ${ }^{14}$ Dengan semakin biasnya ,batas-batas antara pesantren salafiyah dan modern ini, maka, sebagaimana yang disampaikan M. Sulthon Masyhud dan M. Khusnurridlo, yang dapat terlihat berbeda antara pesantren modern dan pesantren salafiyah adalah hanya pada hal-hal yang terdapat pada aspek manajemen, organisasi, dan administrasi pengelolan keuangan yang lebih transparan. ${ }^{15}$

Dunia modern tampaknya turut mengubah relasi antara kiai pesantren modern dengan santri, dari relasi paternalistik menjadi relasi yang semakin fungsional. Seorang kiai kini tak lagi mengurusi semua hal tentang pesantren. Pengelolaan pesantren modern diserahkan sepenuhnya kepada para pengurus. Terkadang pengurus tersebut adalah anak sang kiai sendiri, atau kadang dari kalangan santri yang sudah lama mondok di pesantren dan mempunyai pengetahuan yang mumpuni serta jiwa kepemimpinan. Selain itu, pesantren modern juga banyak yang sekaligus menjadi sebuah yayasan untuk berjaga-jaga agar pesantren tidak lenyap bersama meninggalnya kiai, bila para ahli waris pesantren tidak mau atau tidak mampu melanjutkan fungsi ayah mereka. Dilihat dari kurikulum dan tradisinya, pesantren modern dapat dengan mudah dibedakan dengan pesantren tradisional. Pesantren modern dalam perkembangannya memasukkan mata pelajaran umum ke dalam kurikulum pesantren. Tidak jarang, bahkan penambahan itu sampai menghilangkan karakteristik sebelumnya, atau menghegemoni tradisi serta mata pelajaran klasik.

${ }^{14}$ Imam Barnawi, Tradisionalisme Dalam Pendidikan Islam, (Surabaya: Al Ikhlas, 1993), hlm. 108.

15 M. Sulthon Masyhud dan M. Khusnurridlo, Manajemen Pondok Pesantren, (Jakarta: Diva Pustaka, cet. 1, 2003), hlm. 14-15. 
Dari fisik, infrastruktur, dan sistem pendidikan, pesantren modern dapat dengan mudah dibedakan dari pesantren salafi atau pesantren tradisional. Bangunanbangunan pesantren modern lebih bersih dan terawat, adanya dapur-dapur siap saji, adanya pakaian seragam, auditorium megah, lapangan olahraga, ruang pengembangan bakat dan keterampilan, hingga laboratorium bahasa. Jikalau dalam pengajian bandongan para santri dalam mengaji tidak ada kewajiban hadir, dalam pesantren modern sudah mulai menata struktur pembelajarannya melalu sistem absensi. Sistem dan pembekalan yang dirancang juga sudah sedemikian rupa, guna mempersiapkan santri menghadapi arus modernitas. ${ }^{16}$

Nilai yang ditanamkan pada lembaga modern ini, tak lagi hanya sebatas pembentukan karakter santri, namun sudah lebih melampaui itu. Santri tak hanya melulu bergelut dengan kitab kuning, tapi juga telah dilengkapi kurikulumnya dengan mata pelajaran seperti di sekolah umum. Di lembaga modern ini, selain dibekali materi agama dan mata pelajaran umum, para santri juga digali potensinya. Para santri kemudian diklasifikasikan sesuai dengan minat dan bakat, yang selanjutnya disebut dengan kelas fakultatif. Alumni pesantren modern biasanya mampu berdikari, meski dalam kemampuan menguasai ilmu nahwu, sharaf, dan fikih kurang begitu mumpuni. Pesantren besar yang berhaluan modern dan masih eksis hingga sekarang itu seperti Pesantren Modern Gontor yang sekarang cabangnya banyak tersebar di beberapa daerah di Indonesia.

Agar lebih spesifik untuk mengidentifikasi pesantren modern, penulis mencoba menyampaikan unsur yang menjadi ciri khas pondok pesantren modern adalah sebagai berikut: 1). Penekanan pada bahasa Arab percakapan, 2). Memakai buku-buku literatur bahasa Arab kontemporer (bukan klasik/kitab kuning), 3). Memiliki sekolah formal di bawah kurikulum Diknas dan/atau Kemenag, 4). Tidak lagi memakai sistem pengajian tradisional seperti sorogan, wetonan dan bandongan. ${ }^{17}$

\footnotetext{
${ }^{16}$ Clifford Geertz, Abangan, Santri, dan Priyayi dalam Masyarakat Jawa, (Jakarta: Pustaka, 1981) hlm. 242.

17 Jamal Ma'mur Asmani, Dialektika Pesantren dengan Tuntutan Zaman, (Jakarta: Qirtas, 2003), hlm. 26-271.
} 
Neny Muthi'atul Awwaliyah

\section{Radikalisme Pesantren}

Pesantren yang bersikap konservatif (fundamentalisme, intelektualisme) dalam menghadapi globalisasi pada umumnya bermuara pada fundamentalisme dan radikalisme. ${ }^{18}$ Globalisasi dipandang sebagai upaya menundukkan semua negara untuk mengikuti super power yakni Amerika. Sehingga, globalisasi disebut juga dengan Amerikanisasi, atau ekspansi universal gagasan dan nilai-nilai Amerika. Karenanya, globalisasi dapat menjadi ancaman kaburnya nilai-nilai Islam. Sejatinya, wajah radikalisme pesantren tidak pernah nyata dalam dinamika pesantren sejak abad ke-15 yang dipelopori Walisongo dan dilanjutkan oleh generasi selanjutnya melalui ulama-ulama ternama, seperti Syekh Mutamakkin, Syekh Nawawi al-Bantani, Syekh Mahfud al-Tarmasi, KH. Hasyim Asyari, KH. Wahab Hasbullah, dan masih banyak lagi. Namun, sejak zaman reformasi ini wajah radikalisme pesantren muncul ke permukaan secara nyata. Pertama, Pondok Pesantren al-Islam, Lamongan terlibat dalam aksi pengeboman Bali yang dilakukan para alumni santrinya, seperti Muchlas dan Amrozi. Kedua, Pondok Pesantren al-Mukmin, Ngruki, Sukoharjo yang dicerminkan ustadz Abu Bakar Ba'asyir sebagai tokoh utama, yang diduga ikut terlibat dalam beberapa aksi kekerasan di tanah air.

Berdasar penelitian Endang Turmudi dan Riza Sihbudi ${ }^{19}$, wajah radikal kedua pondok pesantren tersebut sebenarnya lebih banyak dilakukan dalam bentuk wacana dan gerakan. Dalam bentuk wacana, dilakukan dengan memberikan materi pengajaran yang berhaluan radikal; seperti penerapan syariat Islam secara kaffah dalam kehidupan individu, masyarakat, dan negara. Mereka berkeyakinan bahwa penerapan syariat Islam akan menyelesaikan persoalan bangsa, masyarakat, dan individu. Namun mereka sejatinya tidak membenarkan cara-cara kekerasan dalam menerapkan syariat Islam tersebut. Proses penerapan syariat Islam dalam pesantren ini adalah melalui jalur pendidikan. Karena, pendidikan dipandang sebagai instrumen dalam sosialisasi penerapan nilai-nilai syariat Islam kepada santri pada khususnya dan masyarakat pada umumnya.

18 Muin, Abd. Pendidikan Pesantren dan Potensi Radikalisme,(Jakarta: Prasasti, 2007), hlm. 20.

19 Turmudi, Endang \& Sihbudi, Riza (ed.). Islam dan Radikalisme di Indonesia,( Jakarta: LIPI Press, 2005), hlm. 135-137. 
Dengan demikian dapat dipahami bahwa setidaknya ada dua hal yang menyebabkan proses radikalisasi di pesantren. Pertama, jaringan intelektual yang dilakukan pesantren modern berasal dari kawasan Timur Tengah yang berwatak keras, militan dan radikal, terutama ajaran Wahabi yang dibawa secara literal ke wilayah Nusantara. Purifikasi adalah produk nyata dari jaringan intelektual Wahabisme dalam bentuk pemberantasan takhayul, bid'ah, dan khurafat. Dalam proses selanjutnya, jaringanin telektual ini meluas, tidak saja berpatokan pada mazhab Wahabisme, tetapi juga mengambil ideologi radikal sejumlah intelektual; seperti Hasan al-Bana, Al-Maududi, Sayyid Qutb, Hasan Turabi, dan lain-lain. Itu sebabnya, psikologi radikalisme yang bergolak di Timur Tengah benar-benar dipraktikkan di tanah air sebagai perjuangan luhur agama.

Kedua, pengajaran agama yang ekslusif dan dogmatik telah melahirkan sikap permusuhan dengan kelompok di luarnya. Istilah Zionis-Kafir seakan menjelma menjadi kesadaran keagamaan untuk melawannya dalam bentuk apapun. Ditambah lagi dengan ideologi jihad yang dipahami sebagai perang melawan kaum Zionis-Kafir, telah menambah deretan sikap radikal. Sehingga aksi kekerasan apapun yang dilakukan umat untuk menghancurkan Zionis-Kafir, yang mereka sebut sebagai musuh-musuh Islam, adalah perjuangan agama yang paling luhur (syahid). Pada dasarnya, pengajaran seperti ini tidak murni sebagai kesadaran otentik masyarakat Islam Nusantara, melainkan pengaruh dari jaringan intelektual dan ideologis yang dibawa dari Timur Tengah. ${ }^{20}$

Fenomena fundamentalisme dan radikalisme ini, jika dicermati, memang bukan semata-mata disebabkan oleh pola pendidikan pesantren saja atau kian sadarnya masyarakat dan meningkatnya pemahaman keagamaan mereka melainkan juga dirangsang oleh realitas yang mengelilingi kehidupan mereka dimana negara dianggap telah gagal mewujudkan kesejahteraan dan keadilan dengan sistem sekuler yang dianutnya. Fakta seperti inilah yang menjadi salah satu faktor pendorong mencari alternatif lain dalam membangun prinsip dan ideologi pembangunan

${ }^{20}$ Zada, Khamami. Islam Radikal: Pergulatan Ormas-ormas Radikal di Indonesia, Jakarta: Teraju, 2007), hlm. 92-95. 
Neny Muthi'atul Awwaliyah

yang diharapkan lebih menjamin terwujudnya kehidupan yang sejahtera dan berkeadilan

\section{E. Pesantren dan Paradigma Liberal}

Pesantren yang ada di beberapa wilayah teritorial Indonesia secara doktrinal mengambil empat gugus pemikiran keagamaan sebagai mainstream pengajaran, yaitu aqidah, fikih, tasawuf, dan kalam. Keempat gugusan ini sampai sekarang masih begitu mempengaruhi alur pikir umat Islam, juga dipelajari dan dijadikan menu sehari-hari para santri baik dengan metode sorogan dan bandongan/weton ${ }^{21}$. Fikih memiliki wilayah garapan yang bernuansa dhahir (eksoterik) dan lebih bersentuhan langsung dengan masalah keummatan, tasawuf lebih bernuansa esoterik, yang menekankan pada pergulatan kemiskinan batin, dan kalam serta filsafat berorientasi pada problem wahyu dan perkaraperkara yang mengedepankan rasionalitas berpikir.

Dari keempat disiplin itu, fikihlah yang paling dominan, dalam arti membentuk perilaku muslim dalam meretas interaksi sosial sesamanya, meskipun aqidah, tasawuf, dan kalam juga tidak bisa diabaikan begitu saja (Al-Jabiry, 1999:164). Ketiganya turut pula memberikan nuansa tersendiri dalam pergulatan fenomena keagamaan di tanah air. Ketika problem sosial-politik semakin memanas dan tidak lagi memberikan ketentraman, maka menggeluti tasawuf merupakan alternatif ritual karena dianggap mampu memberikan kedalaman spiritualitas serta berhasil mengatasi kedangkalan batin.

Namun, akhir-akhir ini terdapat fenomena lain yang menggejala dalam dunia pesantren. Terdapat dua hal yang bisa dijadikan potret cara berpikir santri yang mengembangkan keperbedaan pandangan. Pertama, secara metodologis, santri mulai sering melakukan persentuhan dengan alur pemikiran dalam kitab-kitab fikih melalui pengembangan cara penyusunan pemikiran hukum itu sendiri (Istinbath Al-Abkam Min Al-Adillat). Ushul fiqh menjadi salah satu kerangka dasar pengambilan metode hukum dalam mencermati problem keagamaan kontemporer. Selain itu kerangka normatif ini tertuangkan dalam sebuah legal maxims (Al-Qawa'id Al-Fiqhiyyah) yang

${ }^{21}$ Dirjosanjoto Pradjarta, Memelihara Ummat. Kiai Pesantren-Kiai Langgar di Jawa, (Yogyakarta: LkiS, 1999), hlm. 149. 
sangat menentukan hasil akhir dari proses ketetapan hukum yang diambil. Kedua, fenomena lain yang menguat adalah perhatian serius pesantren untuk menggeluti kajiankajian perbandingan mazhab dalam fikih. Tentunya, hal ini sangat berpengaruh terhadap pandangan untuk menghargai keperbedaan pemikiran dalam Islam. Penerimaan santri untuk mengkaji kitab Bidayah al-Mujtahid karya Ibnu Rusyd dinilai sebagai langkah maju dari pergeseran pemikiran fikih kaum santri. Sikap inklusif yang dikedepankan telah meruntuhkan pandangan usang tentang pesantren sebagai kumpulan komunitas yang konservatif, primordial, eksklusif, dan anti-perubahan. ${ }^{22}$ Pada masa-masa selanjutnya, pergeseran nuansa di pesantren terjadi. Seiring dengan menyeruaknya arus globalisasi dan modernisasi, pesantren mau tidak mau turut melakukan adaptasi. ${ }^{23}$

Jika dulu pesantren tidak membolehkan para santri untuk membaca koran, menonton televisi, tau mempelajari literature umum, maka sekrang hal-hal seperti bukan lagi merupakan ketabuhan. Banyak pesantren yang kemudian memasukkan beberapa disiplin ilmu baru, bahkan banyak pula yang mendirikan sekolah umum di dalam lingkungan pesantren itu sendiri. Persetruan-persetruan dengan dunia luar ini ternyata sangat berpengaruh terhadap pola pikir kaum santri terhadap doktrin agama yang selama ini dipelajari. Akhirnya, tuntutan-tuntutan baru untuk merespon tantangan modernitas haruslah sesegera mungkin di lakukan. Melalui metode istinbath hukum yang di kuasai, pesantren mulai mengutak-atik persoaan kontemporer tanpa kehilangan spirit keislamannya, atau dengan bahasa lain tetap mengedepankan kaidah Al-Muhafazhah ala Al Qadim Al-Shalih wa Al-Akhdzu bil Jadid Al-Ashlah (memelihara tradisi lama yang masih bernilai baik dan merajut pembaruan yang lebih baik). Bukan hanya dalam bidang hukum Islam, dalam bidang mu'amalah pun, liberalisasi pemikiran juga dilakukan.

Salah satu contoh yang menguat adalah beralihnya fenomena hubungan antar ummat beragama. Jika dulu islamisasi sangat kontras kaitannya dengan kristenisasi

${ }^{22}$ Bisri Effendy, Transformasi Ummat di Tengah Ajaran Agama Baku, Prisma, (Jakarta: LP3ES, No.3, Thn. XX. 1991), hlm. 6.

${ }^{23}$ F. De Haan, Priangan,(Bataviasch Genootschap van Kunsten en Wetenschapen,Vol. III-IV 1995), hlm. 367. 
Neny Muthi'atul Awwaliyah

sehingga menimbulkan kecurigaan antara satu dengan yang lainnya, maka konflik epistemologis di wilayah itu mulai dikikis. Tercetuslah dasar-dasar saling pengertian antar ummat beragama melalui pemahaman dan penafsiran baru terhadap tiga bentuk ukhuwwah, yaitu Ukhuwwah Islamiyyah (persaudaraan islami), Ukhumwah Wathaniyyah (persaudaraan sebangsa), dan Ukhumwah Basyariyyah (persaudaraan sesama manusia). Dari beberapa contoh pergeseran (pembaruan pemikiran) di pesantren ini setidaknya menjadi tolok ukur bahwa komunitas santri bisa sangat adaptif terhadap perkembangan-perkembangan baru yang datang dari luar pesantren. ${ }^{24}$

Liberalisme pesantren bukan hanya dimaknai sebagai keberanian untuk mengaduk-aduk teks-teks kegamaan dengan perangkat metodologi yang memadai, melainkan juga melakukan strategi-strategi pembacaan terhadap teks agama itu sendiri agar kontinuitas untuk melakukan produksi makna baru yang relevan dengan kondisi kekinian. ${ }^{25}$ Apalagi ditambah dengan masuknya gagasan liberal yang dibawa dari Barat. Ideologi demokrasi, civil society, pluralisme, dan bahkan gugatan kritis terhadap Kitab Suci (al-Qur'an dan Hadis Nabi SAW.) telah merambah ke wilayah pesantren, yang selama ini dianggap mewarisi tradisi keilmuan yang standar, tidak kritis, dan terkesan jumud.

Liberalisme dalam lingkungan pesantren memang membawa sisi positif tetapi ada pula sisi negatif. Ia telah mengantarkan pemikiran keislaman yang bersifat toleran, terbuka, dan berkemajuan dalam menghadapi persoalanpersoalan global seperti demokrasi, pluralisme, kesetaraan jender dan modernisasi. Tapi yang harus diamati adalah bahwa Islam liberal telah kehilangan semangat pelacakan otentifikasi Islam, yang sesungguhnya telah tersedia dalam khazanah Islam klasik

Rumadi $^{26}$ mengungkapkan bahwa pesantren sebagai komunitas keilmuan ikut berinteraksi dengan paradigm liberal. Ada dua hal yang dapat dijadikan ukuran untuk melihat masuknya gagasan liberal di komunitas pesantren. Pertama, dilihat dari sudut pemikiran tokoh-tokoh atau pemimpin pesantren. Hal ini dapat dilihat dari beberapa

${ }^{24}$ A. Abaza,. Islamic education perceptions and exchanges: Indonesian students in Cairo, (Paris: Cahier d'Archipel, 1994), hlm. 23.

${ }^{25}$ Majalah Kiblat NO. 9/XXXIII, 85, hlm. 56.

${ }^{26}$ Rumadi, Menebar Wacana, Menyodok Tradisi: Geliat Mencari Makna Liberalisme, dalam Jurnal (Tashwirul Afkar, Edisi No. 9. 2000), hlm. 21-35. 
nama tokoh/pemimpin pesantren yang sudah bersentuhan dengan gagasan liberal, misalnya (alm) K.H abdurrahman wahid, K.H. Said Agil Siradj, KH. Masdar Farid Mas'udi. Tak ketinggal pula, KH.Hussein Muhammad, sebagai satu-satunya ulama/kiai pesantren yang menekunkan hubungan islam dengan gender.

Kedua, dilihat dari lembaga pesantren melalui santrisantrinya yang ikut meramaikan pergulatan diskursif Islam liberal. Sebut saja, Pondok Pesantren Ma’had Ali Situbondo yang berdiri 4 Agustus 1991 yang menurut Marzuki Wahid ${ }^{27}$ telah melakukan diskusi-diskusi wacana keagamaan kontemporer yang tidak lagi menampilkan wajah Islam yang tertutup dan konservatif, yang ditunjukkan dari beberapa indikator: 1) Berdirinya Fokus Kajian Ushul Fikh pada tahun 1998. Kelompok kajian ini di samping mengkaji pemikiran ushul fiqh klasik, juga dilengkapi dengan pemikiran fikh dan ushul fikh yang lebih kontemporer, termasuk pemikiran Mahmoed Muhammad Thaha, Abdullahi Ahmed an-Na'im, Hasan Turabi, Jamal alBanna, dll. 2) Pusat Studi Agama dan Filsafat, yang secara serius menyelenggarakan diskusi-diskusi filsafat, baik filsafat Islam maupun filsafat Barat. Pusat Studi ini akrab dengan pemikiran para tokoh non-Muslim yang dikenal berhaluan kiri, seperti pemikiran Mao, Karl Marx, Max Weber, dll. 3) Buletin mingguan 'Tanwirul Afkar' membahas masalah kontemporer dengan analisis sosial dan analisis fiqhiyyah. Kini telah menjadi sebuah buku yang berjudul 'Fikh rakyat: Pertautan Fikh' dengan kekuasaan yang diterbitkan LKiS Yogyakarta.

Narasumber atau dosen tamunya pun lebih sering menggunakan pemikir yang berani melakukan pemikiran kritis, seperti $\mathrm{KH}$. Abdurrahman Wahid, $\mathrm{KH}$ sahal Mahfudh, KH Ali Yafie, Prof Dr. Quraish Shihab, Prof. Dr. Nurcholish Madjid. KH Masdar F. Mas'udi, KH. Said Agil Siradj, KH. A. Muhith Muzadi. Dari sinilah terjadi kontak gagasan yang beraneka ragam di antara santri dan para ustadnya yang lintas pemikiran dan mazhab. Pergulatan intelektual yang terjadi di Ma'had Ali Situbondo ini bisa dikelompokkan sebagai salah satu prototype dari pesantren liberal, meski dalam batas-batas tertentu tidak bisa dianggap sebagai pesantren liberal. Tetapi paling tidak 47.

27 Wahid, Marzuki. Dkk, Pesantren Masa Depan, (Bandung: Pustaka Hidayah, 2004), hlm. 45- 
Neny Muthi'atul Awwaliyah

Ma'had Ali Situbondo dianggap telah menerima pemikiran liberal yang dibawa dari luar.

\section{F. Respon Pesantren Terhadap Globalisasi}

Globalisasi merupakan suatu era global dimana dunia terasa seperti sebuah kampung kecil. Interaksi antar negara, peradaban dan budaya semakin mudah dilakukan. Proses salingmempengaruhiantar satu budaya dengan budaya yang lain semakin intens dan dengan proses yang cepat, baik budaya itu bersifat positif atau pun negatif sehingga pada akhirnya globalisasi menjadi alat untuk saling mempengaruhi antar peradaban, budaya, ideologi bahkan agama.

Proses saling mempengaruhi tersebut menjadikan suatu peradaban, budaya dan agama terkontaminasi dengan unsur- unsur yang lain.Hal ini menimbulkan kegoncangan bagi ideologi dan budaya lain yang tidak sesuai karakteristik sosial kulturalnya, termasuk juga dialami oleh lembaga pendidikan Islam seperti pesantren. Secara umum, paradigma yang berkembang di kalangan umat Islam dalam menghadapi globalisasi adalah: Pertama, paradigma konservatif. Paradigma ini cenderung memposisikan Pesantren sebagai lembaga peragama yang memiliki doktrin dan ikatan-ikatan tradisi lama yang belum mau bersentuhan dengan wacana keilmuan selain Islam. unsur-unsur sosial selain Islam dalam hal ini dianggap sebagai bagian yang senantiasa berlawanan bahkan mengancam.

Paradigma seperti ini didasarkan pada perspektif holistik, yang memposisikan hubungan antara agama Islam dan persoalan kemasyarakatan sebagai sesuatu yang tak terpisahkan. Menurut mereka, Islam bukanlah semata-mata agama dalam pengertian Barat, yakni hanya menyangkut hubungan antara manusia dan Tuhan, melainkan Islam adalah agama yang sempurna dan lengkap yang mengatur segala aspek kehidupan manusia, sehingga doktrin dan ikatan-ikatan tradisi lama yang ada tidak dapat bersentuhan dengan wacana keilmuan selain Islam, termasuk menganggap bahwa globalisasi adalah unsur yang sangat mengancam bagi keberlangsungan nilainilai Islam. Kedua, paradigma liberal. Pesantren yang mengusung paradigma ini mengasumsikan bahwa Islam adalah agama yang dapat berperan sebagai agen perubahan sosial. unsur- unsur sosial selain Islam dalam hal ini menjadi komponen 
yang diterima bahkan menjadi acuan penting di dalam merumuskan berbagai solusi terhadap persoalan kekinian yang dihadapi umat.

Dalam dimensi teologi paradigma ini mengedepankan aspek rasionalisme. Teologi bukan semata menjadi objek kajian bagaimana meyakinkan umat secara doktriner, melainkan sebagai pembimbing tindakan praksis sosial. Selain itu, teologi juga harus lepas dari paradigma kekuasaan negara, bahkan harus menjadi bagian transformasi sosial yang terus menyuarakan kepentingan mayoritas umat. Paradigma ini berpendirian bahwa walaupun Islam memiliki doktrin dan ikatanikatan tradisi lama tapi harus dilakukan banyak dekonstruksi terhadap pemahaman doktrin tersebut. $^{28}$

Berkebalikan dengan teologi kaum konservatif yang gigih membela Tuhan, dimensi teologi yang mereka ajukan justru menginginkan konsistensi menjelmakan nilai tauhid sebagai ajaran yang membebaskan umat dari penindasan kultural dan struktural. Mereka lebih menekankan pembelaan terhadap nilai-nilai kemanusiaan, sehingga terkadang melampaui garis-garis 'larangan' demi mewujudkan teologis humanisnya. Dalam dimensi syariat paradigma ini mengambil hukum-hukum melalui pemahaman yang cenderung terlalu kontekstual, sehingga terkadang mengabaikan tekstualitas dan latar belakang munculnya doktrin-doktrin agama. Mereka juga mengajukan berbagai wacana tentang perlunya tafsir ulang terhadap alQur'an dan hadis.

Ketiga, paradigma moderat. Pesantren yang mengusung paradigma ini mencoba mengkompromikan dua paradigma di atas, yang cenderung mencoba mengintegrasikan pandangan-pandangan yang antagonistik dalam melihat hubungan Islam dan persoalan kemasyarakatan, sekaligus ingin melunakkan Paradigma Konservatif yang seringkali melakukan generalisasi bahwa Islam selalu mempunyai kaitan atau hubungan yang tak terpisahkan dengan masalah-masalah kemasyarakatan. Serta berusaha mengakomodasi dilakukannya pembaruan wacana

${ }^{28}$ Kurniawan, H., Rhamadon, M.A., Sari, A. Peran Alumni Al-Azhar Mesir dalam Mewnjudkan Kebidupan Beragama yang Damai dengan Mengembangkan Ajaran Moderasi Islam di Indonesia. Jurnal Middle East and Islamic Studies (MEIS). Vol. 3. No. 6. Desember, 2014, hlm. 67-68. 
Neny Muthi'atul Awwaliyah

sesuai dengan diinginkan kalangan liberal dengan tetap memperhatikan nilai-nilai luhur dan keislaman.

Sesuai dengan konsep Islam sebagai agama wasathan (moderat), maka dalam melihat hubungan Islam dan negara, paradigma moderat menolak pendapat bahwa Islam adalah agama yang serba lengkap dan bahwa dalam Islam terdapat sistem ketatanegaraan. Tetapi kelompok ini juga menolak anggapan bahwa agama adalah dalam pengertian barat yang hanya mengatur hubungan manusia dengan Tuhan. Paradigma ini juga berpendirian bahwa dalam Islam tidak terdapat sistem ketatanegaraan tetapi terdapat seperangkat tata nilai etika bagi kehidupan bernegara.

Pesantren yang berpegang pada paradigma ini tidak hanya ingin menonjolkan isu seputar konsep 'Negara Islam' dan 'Pemberlakuan syariat', tetapi yang paling penting bagaimana substansi dari nilai dan ajaran agama itu sendiri. Agama adalah sejumlah ajaran moral dan etika sosial, selain itu agama juga berfungsi sebagai alat kontrol negara. Paradigma moderat berpandangan, keterlibatan agama secara praktis ke dalam negara jangan sampai memandulkan nilai luhur yang terkandung dalam agama karena agama akan menjadi ajang politisasi dan kontestasi. Di sisi lain, paradigma ismam moderat mengkampanyekan dimensi yang sifatnya lentur, santun, dan beradab. Hal ini penting guna meminimalisir pandangan keagamaan yang selalu berwajah sangar dan keras yang digunakan secara sistematis oleh beberapa kalangan muslim.

\section{G. Peran Para Santri dalam Pengembangan Moderasi Islam}

Menurut pengertian yang umum dipakai di lingkungan pesantren, santri merupakan elemen penting, yang menurut tradisinya dapat dikelompokkan menjadi santri 'mukim' dan santri 'kalong'. Kelompok santri yang pertama, yaitu santri mukim, adalah para pelajar yang berasal dari daerah-daerah terjauh yang menetap di lingkungan pesantren. Kalangan santri yang paling lama tinggal di pesantren biasanya dikenal sebagai 'ustadz'. Mereka ini merupakan satu kelompok tersendiri yang memegang tanggung jawab mengurusi kepentingan pesantren sehari-hari, memikul tanggungjawab mengajar santri-santri muda tentang kitab-kitab dasar dan menengah. Dalam sebuah pesantren besar akan terdapat anak-anak para kiyai dari pesantren 
tersebut dengan sebutan 'gus' yang juga belajar di sana. Mereka ini biasanya akan menerima perhatian istimewa dari para kiyai. Adapun kelompok santri yang kedua, yaitu kelompok santri kalong, adalah para pelajar yang berasal dari desa-desa di sekitar pesantren, yang biasanya tidak menetap di dalam lingkungan pesantren. Para santri ini datang dan pergi dari rumah-rumah mereka ke pesantren untuk mengikuti pelajarannya.

Perbedaan antara pesantren besar dan kecil dapat dilihat dari komposisi santri kalong di dalamnya. Semakin besar sebuah pesantren, maka akan semakin besar pula jumlah santri mukim-nya. Dengan kata lain, pesantren kecil akan memiliki lebih banyak santri kalong, dari pada santri mukim-nya. Pada masa lalu, kepergian seseorang untuk menetap di sebuah pesantren yang jauh dan masyhur merupakan suatu keistimewaan bagi seorang santri yang penuh dengan cita-cita. Mereka diharapkan memiliki keberanian yang cukup, penuh ambisi, serta harus mampu menekan perasaan rindu kepada keluarga dan teman-teman sekampung mereka, dengan harapan jika setelah selesai menimba ilmu di pesantren mereka mampu mengajarkan ajaran Islam dari kitab-kitab yang mereka pelajari, serta mampu memimpin dalam setiap kegiatan keagamaan dalam masyarakat, di mana mereka berasal.

Mereka juga diharapkan mampu memberikan nasihat serta solusi mengenai persoalan-persoalan kehidupan masyarakat, baik secara individual maupun keompok yang berkaitan dengan permasalahan keagamaan. Maka, tidak mengherankan jika biasanya hanya seorang calon santri yang penuh kesungguhan, serta pengharapan atas keberhasilan lah yang akan diberi kesempatan untuk belajar di pesantren yang lebih jauh.

Islam mengajarkan bahwa perjalanan dalam mencari ilmu adalah suatu kewajiban bagi para pemeluk ajarannya. Meski pendidikan sangat ditekankan dalam Islam, dimana prinsip dasarnya adalah tidak mengharapkan imbalan atau keuntungan yang bersifat material, namun pada kenyataannya pendidikan bagi seseorang itu sangatlah mahal. Oleh karena biaya untuk belajar di pesantren besar pada waktu dulu (dan juga berlaku pada saat sekarang) dipandang sangat mahal bagi kalangan 
Neny Muthi'atul Awwaliyah

menengah kebawah, baik dari ongkos perjalanan, biaya hidup, serta kitab-kitab yang harus mereka pelajari, maka biasanya biaya tersebut tidak hanya ditanggung oleh keluarga santri yang bersangkutan, tetapi juga dibantu oleh oleh keluarga dekat, atau tetangga, atau keluarga kaya yang akan memanfaatkan santri yang bersangkutan di kemudian hari, bahkan terkadang masyarakat sekampung yang peduli, sehingga si santri tersebut akan dengan sungguh-sungguh menempa diri dalam studinya, dikarenakan harapan keluarga dan masyarakat yang begitu besar terhadapnya.

Di pesantren yang lebih kecil, pada dasarnya para penyelenggara di sana menyediakan pendidikan yang bebas (tidak memungut biaya), dikarenakan lembaga pesantren itu sendiri sekaligus juga para santrinya tidak memerlukan ongkos yang banyak. Sebagian para santri dapat tinggal bersama penduduk desa setempat tanpa harus membayar biaya kebutuhan sehari-hari. Para santri di sana biasanya berperan sebagai pelajar, pendidik, pendakwah, sekaligus juga pengabdi masyarakat dalam bidang pertanian, peternakan, dan industri kecil dengan cara turut membantu mengerjakan sawah, kebun, ladang dan pabrik rumahan milik penduduk sekitar.

Singkatnya, para santri yang yang menerima pendidikan pesantren, baik di pesantren kecil maupun besar, adalah orang-orang yang pada kenyataan sebenarnya berasal dari keluarga atau kalangan masyarakat yang berkecukupan. Realitas ini dapat menerangkan sebagian dari alasan mengapa banyak dari para kyai-yang dipengaruhi oleh budaya santri di pedesaan-justru mampu berhaji berkali-kali, bahkan mampu mengirimkan anak-anak mereka untuk belajar ke luar negeri di Timur Tengah, justru dikarenakan kebanyakan dari mereka merupakan keluarga petani atau pebisnis di pedesaan yang mampu dan berkecukupan. Meski demikian, belum dapat disimpulkan bahwa pengelompokkan kaum 'santri' dan kaum 'abangan' di kalangan pedesaan menggambarkan pula pengelompokan antara mereka yang berstatus sosial yang tinggi dengan yang berstatus sosial yang rendah. Sebab, fakta waktu itu menunjukkan bahwa hanya sebagian keluarga yang mampu saja yang dapat mengikuti pendidikan pesantren, dan banyak pula keluarga petani miskin, yang lebih intensif mengikuti 
budaya santri-yang berasal dari budaya perkotaan-dari teman-teman sedesa mereka yang kaya. ${ }^{29}$

Dari sekelumit kehidupan para santri sekaligus peran mereka sebagai pelajar, pendidik, pendakwah, sekaligus pengabdi masyarakat di waktu dulu, pada saat sekarang ini justru kalangan Islam menghadapi paling tidak dua tantangan besar, yaitu kecenderungan sebagian kalangan santri yang bersikap ekstrim dan ketat dalam memahami hukum-hukum agama dan mencoba memaksakan cara pemikiran Timur Tengah di kalangan masyarakat, serta kecenderungan lain yang juga bersifat ekstrim dengan bersikap longgar dalam beragama dan tunduk pada perilaku serta pemikiran lain yang berasal dari budaya dan peradaban Barat.

Kedua sikap ini tidak menguntungkan umat Islam dan lembaga-lembaga pendidikan Islam itu sendiri untuk saat ini. Kecenderungan pertama telah memberikan citra negatif kepada para santri dan lembaga pesantren secara luas sebagai komunitas masyarakat yang dianggap konservatif, eksklusif, dan ekstrim, yang mengajarakan kekerasan dalam dakwahnya. Sementara, kecenderungan kedua mengakibatkan para santri kehilangan jati diri mereka karena melebur dan larut dalam budaya dan peradaban lain yang lebih longgar, liberal, bahkan tidak terarah. Artinya, kelompok yang pertama terlalu ketat bahkan cenderung menutup diri dalam sikap keberagaman, dan kelompok yang kedua terlalu longgar dan sangat terbuka, sehingga mengaburkan esensi ajaran agama Islam itu sendiri.

Ajaran Al-Wasathiyah (moderat) yang dikembangkan lebih jauh oleh para santri di Indonesia, sebagaimana tercermin dalam ajaran Islam antara lain dalam hal akidah (keyakinan), ibadah (pelaksanaan hukum dan ritual keagamaan), dakwah (syiar agama), dan akhlak (etika). Adapun konsep Al-Ghuluw ( melampai batas) dalam beragama yang selalu diperingatkan oleh kiyai kepada para santrinya adalah upaya untuk menjauhi fanatisme yang berlebihan terhadap salah satu pandangan, kecenderungan yang justru mempersulit pelaksanaan ajaran Islam, berprasangka buruk kepada penganut agama lain, atau bahkan pengkafiran terhadap sesama muslim

29 Z. Dhofier, Tradisi Pesantren: Studi tentang Pandangan Hidup Kiyai, (Jakarta: LP3ES, 1982), hlm. 74-76. 
Neny Muthi'atul Awwaliyah

yang berbeda pemikiran dengannya. Sementara, sikap-sikap moderat para santri yang dapat dikembangkan di masyarakat adalah beberapa metode pemahaman dan pengamalan teks-teks keagamaan yang ditandai dengan beberapa ciri seperti pemahaman terhadap realitas (figh al-waqi), pemahaman terhadap fiqh prioritas (fiqh al-auwlawiyyat), pemahaman terhadap konsep sunatullah dalam penciptaan mahluk, pemahaman terhadap teks-teks keagamaan secara komprehensif, pemberian kemudahan kepada orang lain dalam beragama, mengedepankan dialog, bersikap toleran, serta sikap keterbukaan dengan dunia luar.

Temuan lapangan dari penelitian yang dilakukan pada tahun 2011 di wilayah Jabodetabek, Nusa Tenggara Barat, Kalimantan Timur dan Sumatra Utara mengindikasikan adanya paham-paham yang berseberangan dengan penganut Islam moderat yang berkembang di daerah tersebut. Kasus yang berkembang di berbagai daerah yang diamati sangat beragam, mulai dari Salafisme, Ahmadiyah, Wahabisme, serta adat-istiadat (tradisi) yang sudah mengakar lama di daerah-daerah tersebut (Kurniawan, dkk. 2014). Beberapa temuan tersebut, yaitu antara lain:

Pertama, adanya heterogenitas kelompok sosial para pelajar dari Timur Tengah di beberapa wilayah tersebut, yang berbaur dengan masyarakat lokal, dimana tradisi dan adat-istiadat mereka bertentangan dengan konsep moderasi Islam, mulai dari kalangan intelektual, tokoh agama dan tokoh masyarakat, politikus, serta pebisnis di perkotaan, sampai pada kelompok kalangan religius di pedesaan, terutama yang berlangsung di wilayah-wilayah yang diamati di Jakarta, Bogor, Depok, Tanggerang dan Bekasi (JABODETABEK).

Kedua, adanya kompleksitas dinamika persoalan umat Islam di wilayahwilayah yang tidak memungkinkan para santri bergerak sendirian dalam mengatasi berbagai persoalan perbedaan pemahaman keagamaan yang kerap muncul di lingkungan tempat mereka berdakwah, yang pada ujungnya dapat berpotensi terhadap konflik, terutama yang berlangsung di sebagian wilayah Jawa dan Kalimantan Timur.

Ketiga, adanya bayangan umum masyarakat di wilayah masing-masing tentang alumni Timur Tengah yang bergaris kanan (fundamentalisme dan radikalisme), 
bergaris kiri (liberalism dan pluralisme), dan yang memilih moderat terutama yang berlangsung di wilayah Sumatra Utara.

Terkait tantangan penyebaran ajaran moderasi Islam dalam ruang lingkup penelitian di beberapa wilayah di Indonesia tersebut di atas, secara lebih spesifik, sebagaimana yang berlangsung di Nusa Tenggara Barat, tantangan tersebut justru datang dari sesama pelaku di lingkungan pesantren itu sendiri, terutama dari kalangan kiyai dan santri mereka yang memiliki latarbelakang pendidikan Timur Tengah, tetapi berasal dari kawasan atau negara yang berbeda seperti Jordania, Mesir, Tunisia, dan Maroko yang cenderung moderat dengan para kiyai sekaligus santri mereka yang berasal dari Arab Saudi, Yaman dan Sudan dengan paham yang terkesan lebih keras dan kerap mengklaim praktik adat-istiadat dan budaya lokal sebagai bid'ah dan menyimpang. Selain itu, tantangan lain juga datang dari para kiyai dan santri yang dinilai lebih liberal dalam masalah-masalah keagamaan. Kedua tantangan ini merupakan tantangan berat yang dihadapi dalam pengembangan ajaran moderasi Islam dalam meluruskan anggapan-anggapan masyarakat terkait adanya kedua kubu yang radikal dan liberal.

Di tempat lain, tantangan dari para kiyai sekaligus santri mereka yang beraliran Wahabisme dan Salafisme dipandang tidak terlalu mengkhawatirkan di Kalimantan Timur. Hal tersebut dikarenakan para santri berusaha masuk ke semua kalangan, bahkan ada beberapa dari mereka yang berusaha membaur dan bergabung dengan lembaga-lembaga Islam yang terkesan eksklusif seperti LDII untuk kemudian memahamkan moderasi Islam kepada mereka dari dalam. Hal ini terbukti efektif dalam menyadarkan pemahaman Islam konservatif yang menutup diri di kalangan para pengikut LDII di Samarinda yang dapat berkoordinasi dengan MUI Kalimantan Timur.

Di tempat lain yang lebih terpencil, yang masih menjadi lokasi penelitian, tepatnya di Desa Loa Duri Ilir dan Bakungan, Kecamatan Loa Janan, Kabupaten Kutai Kartanegara, penyebaran pemahaman moderasi Islam diimplementasikan kedalam program kegiatan dakwah yang diselenggarakan oleh pemerintah provinsi Kalimantan Timur dengan melibatkan para santri dari berbagai pesantren. Hal paling 
Neny Muthi'atul Awwaliyah

mendasar yang dilakukan oleh para santri di sana adalah menyadarkan para penduduk pedalaman Loa Duri Ilir dan Bakungan dari kebudayaan animisme dan dinamisme untuk kembali pada dasar-dasar dan prinsip-prinsip tentang agama monotheisme (tauhid).

Temuan lain dari penelitian lapangan ini menunjukkan bahwa sebagian besar kaum terpelajar di kalangan santri yang ada di berbagai lokasi, terutama di Nusa Tenggara Barat, memiliki peran-peran yang lebih kulturalis, sinergis, aktif, partisipatif dan berkesinambungan dengan masyarakat sekitar. Hal tersebut tidak lepas dari peran para santri tersebut yang justru telah lama menjalankan jargon 'tridarma perguruan tinggi' yaitu terus aktif dalam bidang pendidikan dan pengajaran, penelitian, serta pengabdian masyarakat. Sebagian dari mereka bahkan meraih kesempatan untuk dapat memposisikan diri dalam kekuasaan sebagai kepala daerah setempat, dimana Gubernur mereka berasal dari kalangan santri. Hal ini diperkuat oleh fakta di lapangan yang menunjukkan adanya harmoni yang berkesinambungan, yang diindikasikan oleh kerjasama antara peran ulama (cendekiawan) dan 'umara' (pemerintah) dalam sebuah pendekatan yang bersifat kultural. Para ulama di sana memiliki dua peran penting, yaitu sebagai kiyai dalam masyarakat yang masih memegang teguh adat-istiadat lokal, serta sebagai penguasa dalam struktur pemerintahan. Berbagai kegiatan konkret yang dilakukan oleh para santri di sana salah satunya dimaksudkan untuk memperkuat soliditas kebersamaan di antara kelompok mereka, terutama yang sama-sama berjuang dalam mensosialisasikan visi dan misi ajaran moderasi Islam.

Dalam interaksi dengan masyarakat luas, terutama dalam pergaulan mereka sehari-hari, para santri di beberapa wilayah pengamatan dituntut oleh lembaga pesantren yang mengirim mereka ke daerah-daerah untuk tidak mudah mendiskriminasi orang lain, terlebih mengkafirkannya tanpa sebab yang jelas. Dalam keyakinan mereka, hal tersebut dilarang dikarenakan akan menimbulkan kekacauan di kalangan masyarakat dan berimplikasi terhadap hukum yang menjadi lebih rumit dan berbuntut panjang. Sebagai konsekwensinya, segala sesuatu yang berhubungan dengan orang yang dikafirkan akan diangap kafir pula hal-hal lainnya, seperti pemisahan hubungan sedarah dengan sanak-familinya, pemisahan hubungan suami 
dan istri, penghilangan hak waris, penelantaran jika yang bersangkutan meninggal dunia (tidak dimandikan, tidak dikafani, tidak dishalatkan, dan tidak dikuburkan di pemakaman orang-orang muslim). Padahal, dalam ajaran Islam, seseorang yang telah mengucapkan dua kalimat syahadat, meskipun ia berada dalam keadaan terpaksa, maka ia adalah seorang muslim yang harus dilindungi, bahkan Nabi pun mengharamkan darah para kafir dzimmy di Medinah yang telah membayar dzimmah untuk dilindungi.

Selain melarang untuk dengan mudah mengkafirkan orang lain dan menyeru untuk bekerja dan beraktivitas di muka bumi, para santri ini juga mangajak warga setempat untuk mempersiapkan diri dan berbekal menuju kehidupan akhirat, yaitu dengan memperkuat keimanan, menjalankan ibadah, serta menjalin hubungan dengan Tuhan mereka. Dalam pengakuan mereka yang sebagian diwawancarai, kehidupan dunia bukanlah penjara tempat manusia disiksa, tetapi sebuah nikmat yang harus disyukuri sebagai ladang untuk mencapai kehidupan kekal di akhirat. Bagi mereka, dunia kerja (yang dianggap sebagai fasilitas) tidak boleh mengabaikan amalan yang mereka persiapkan untuk akhirat. Meski demikian, catatan hasil pengamatan menunjukkan bahwa para santri yang diamati juga memiliki peran-peran yang tidak didasarkan semata-mata kepada persoalan immaterial, tetapi mereka juga memikirkan persoalan masa depan yang bersifat material.

Dari beberapa kenyataan yang ditemukan di lapangan membuktikan bahwa ajaran moderasi Islam dalam pendidikan pesantren mampu menghadirkan identitasnya sebagai poros tengah yang terpusat dalam gerakan Islam moderat di antara dua kubu yang berbeda haluan, yaitu gerakan Islam kontemporer yang cenderung liberal dan gerakan Islam konservatif yang lebih radikal. Beberapa agenda utama dari pengembangan ajaran ini adalah: (1) memperbaiki citra Islam—sebagai rahmat bagi semesta alam-yang dipandang negatif di masyarakat internasional; (2) membangun keseimbangan (harmoni) dan membumikan kerukunan (toleransi) di antara kelompok-kelompok yang berbeda, baik di luar Islam maupun di dalam Islam itu sendiri; (3) memastikan bahwa paham moderasi tidak melampaui garis-garis primer (tsawabit) yang terdapat dalam ajaran Islam; serta (4) menebarkan perdamaian di muka bumi dengan membangun dialog intra-religious dan inter-faith. Alasan 
Neny Muthi'atul Awwaliyah

beberapa agenda utama tersebut adalah bahwa perbedaan paham keagamaan adalah entitas yang patut dilindungi dan dihormati sesuai prinsip ‘menerima yang lain’ (qabul al-akhar).

\section{H. Kesimpulan}

Sejalan dengan globalisasi, wajah pesantren di Indonesia sudah tidak lagi dimonopoli oleh kelompok Islam tradisional atau fundamental-radikal, melainkan sudah diwarnai oleh pesantrenpesantren baru yang dibentuk oleh kelompok Islam lainnya dengan wajah pesantren yang berbeda pula. Dari visi, tujuan, pola pendidikan, serta literatur yang digunakan, tampak bahwa pesantren yang berwajah radikal berkiblat kepada model Islam Timur Tengah. Sementara pesantren lama yang mendirikan lembaga baru di lingkungan pesantren, seperti kasus Ma'had Ali Situbondo menampilkan wajah pesantren yang akomodatif terhadap perubahan dan gagasan-gagasan baru.

Kiprah para kaum terpelajar dari kalangan santri, baik yang berada di pedesaan maupun di perkotaan, sedikit banyak telah membawa dampak positif dalam model pendidikan serta pengembangan ajaran moderasi Islam di berbagai kalangan serta kelas-kelas masyarakat. Masyarakat yang melihat langsung peran nyata para santri ini dapat turut merasakan manfaat dalam bidang keilmuan, pendidikan, konsultasi, serta penyelesaian berbagai masalah sosial yang membawa masyarakat ke arah lebih baik dari sebelumnya.

Sebagian masyarakat yang didatangi oleh para santri tersebut turut mengeluhkan dampak dari minimnya jumlah para santri yang mau turun ke daerah terpencil, dimana kesempatan serta agenda pekerjaan yang harus digarap masih terbuka luas bagi para santri untuk mengabdi di masyarakat. Masyarakat juga mengharapkan agar penyebaran tenaga-tenaga pendidik keagamaan yang lebih moderat tidak hanya berkisar di perkotaan, tetapi juga dapat tersebar merata ke daerah-daerah pelosok. Pada kenyataannya, para santri sekarang ini sedikit sekali yang berminat dan terpanggil untuk mengabdi ke pelosok-pelosok terpencil, tetapi justru banyak yang melanjutkan studi dan bekerja di perkotaan, sehingga penyebarannya banyak terpusat di perkotaan. 
Dengan demikian, radikalisme dan liberalisme sebuah pesantren sangat tergantung para pemimpin pesantren tersebut (pemilik, kyai, atau santri senior). Jika arus pemikiran para pemimpinnya berkarakter radikal, maka pesantren dan isinya memiliki kecenderungan berpandanagan radikal, sedangkan jika para pemimpinnya berkarakter moderat, maka sebuah pesantren beserta santrinya berkarakter moderat, bahkan bisa menjadi liberal dalam situasi dan waktu tertentu. 
Neny Muthi'atul Awwaliyah

\section{Daftar Pustaka}

De Haan, F. 1912, Bataviasch Genootschap van Kunsten en Wetenschapen, Priangan, Vol. III-IV.

Dhofier, Z. 1982, Tradisi Pesantren: Studi tentang Pandangan Hidup Kyai, Jakarta: LP3ES.

Dirjosanjoto, Pradjarta. 1999, Memelihara Ummat. Kiai Pesantren-Kiai Langgar di Jawa, Yogyakarta: LKiS.

Effendy, Bisri. 1991, Transformasi Ummat di Tengah Ajaran Agama Baku, Prisma, Jakarta: LP3ES, No.3, Thn. XX.

Geertz, Clifford. 1981, Abangan, Santri, dan Priyayi dalam Masyarakat Jawa, Jakarta: Pustaka

1956, Religious Belief and Economic Behavior in a Central Javanese Town: Some Preliminary Considerations, dalam Economic Developement and Cultural Change, Vol. IV, No. 2, Januari. 1960, The Religion of Java, The Free Press of Glencoe. 1960, The Javanese Family, The Free Press of Glencoe. 1963, Modernization in a Moslem Society: The Indonesian Case, QUEST, Vol. 39 Bombay. 1968, Islam Observed. New Haven London: Yale University Press.

Majalah Kiblat NO. 9/XXXIII, 85: hlm. 56.

Muin, Abd. 2007, Pendidikan Pesantren dan Potensi Radikalisme, Jakarta: Prasasti.

Rumadi. 2000, Menebar Wacana, Menyodok Tradisi: Geliat Mencari Makna Liberalisme, dalam Jurnal Tashwirul Afkar, Edisi No.9

Sutrisno, Budiono Hadi. 2009, Sejarah Walisongo Misi Pengislaman di Tanah Jawa. Yogyakarta: GRAHA Pustaka. 
Turmudi, Endang \& Sihbudi, Riza (ed.). 2005, Islam dan Radikalisme di Indonesia, Jakarta: LIPI Press.

Wahid, Marzuki. dkk (ed.). 1999, Pesantren Masa Depan, Bandung: Pustaka Hidayah.

Yusuf, Choirul \& Suwito NS. 2009, Model Pengembangan Ekonomi Pesantren, Purwokerto: STAIN Press.

Zada, Khamami. 2002, Islam Radikal: Pergulatan Ormas-ormas Radikal di Indonesia, Jakarta: Teraju. 